\title{
Keratosis punctata of the palmar creases in a 68-year-old African-American man
}

\author{
Alex K Bonnecaze, ${ }^{1}$ Wesley Willeford ${ }^{2}$
}

${ }^{1}$ Department of Internal Medicine, Wake Forest University School of Medicine, Winston-Salem, North Carolina, USA

${ }^{2}$ Department of Internal Medicine, Wake Forest University, Winston-Salem, North Carolina, USA

\section{Correspondence to}

Dr Alex K Bonnecaze, abonneca@wakehealth.edu

Accepted 28 June 2016

\section{DESCRIPTION}

A 68-year-old African-American man with a history of duodenal adenocarcinoma was found to have innumerable $1 \mathrm{~mm}$ hyperkeratotic depressions along his palmar creases bilaterally (figures 1-3). The patient reported having these lesions since early in childhood. He also noted that all men in his family, dating back to his great-great-grandfather, had similar palmar crease pitting. He stated he was diagnosed with keratosis punctata of the palmar creases (KPPC) at an early age and failed to respond to prior therapies including topical retinoid cream and emollients. He denied any pain or prior infections to the sites; however, he did note occasional white pustular appearing discharge from some pits.

KPPC is a benign condition which features innumerable sharply marginated, hyperkeratotic $1-5 \mathrm{~mm}$ depressions along the palmar creases. It most often affects African-Americans with an estimated

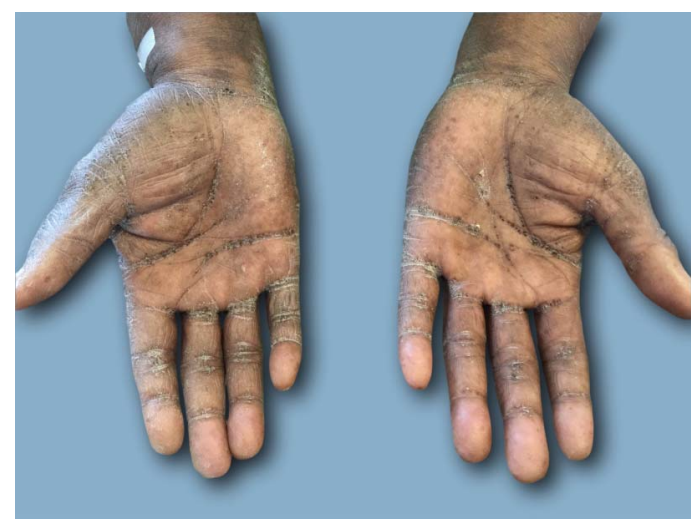

Figure 1 Innumerable hyperkeratotic pits limited to the bilateral palmar creases.

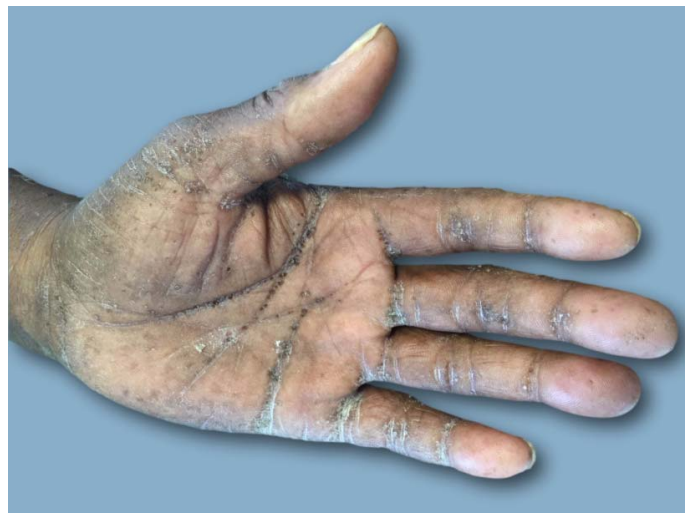

Figure 2 Left palmar surface further demonstrating hyperkeratotic pitting.

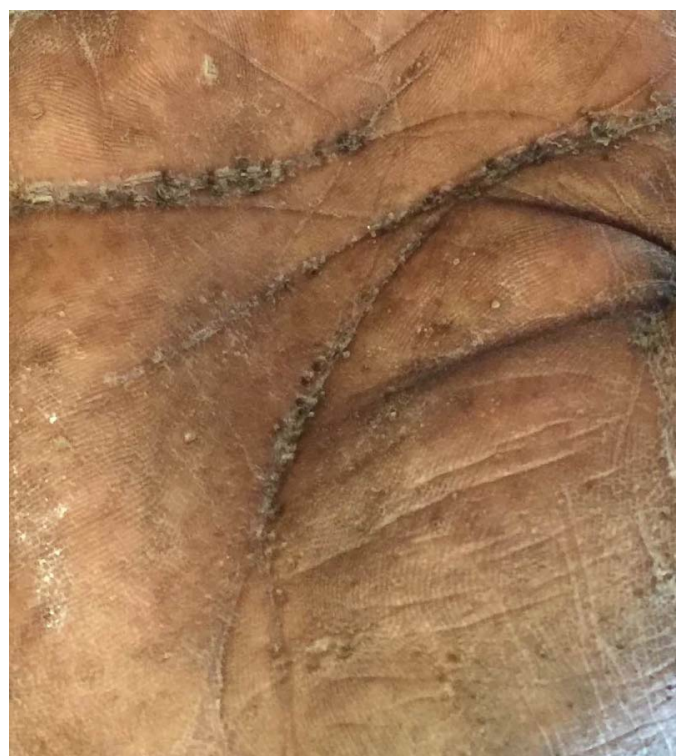

Figure 3 Close-up view of the left palmar surface.

prevalence of $1.9-3.1 \%$ in this population. ${ }^{1}$ Inheritance is believed to be autosomal dominant; however, some cases appear to be sporadic. KPPC is commonly associated with Dupuytren's contraction, knuckle pads and striate keratoderma, none of which the patient had. Treatment includes topical keratolytics, such as salicylic acid and emollients.

\section{Learning points}

Keratosis punctata of the palmar creases (KPPC) is a benign condition most commonly seen in African-American patients (1.9-3.1\%) which features many $1-5 \mathrm{~mm}$ sharply defined hyperkeratotic pits limited to the palmar creases.

- Treatment options include topical keratolytics, emollients and occasionally systemic retinoids for severe cases. Systemic retinoids, such as etretinate, carry the risk of associated side effects such as hepatotoxicity. Reassurance that this is a benign condition is also helpful, as the appearance can often be concerning to patients.

- KPPC should not be confused with keratosis punctata palmoplantaris (KPPP), a rare condition featuring pitting of the palmoplantar surfaces, as opposed to being limited to the palmar creases. While KPPC is a benign process, KPPP carries the associated risk of colorectal malignancy. 


\section{Images in...}

Systemic retinoids, such as etretinate, are occasionally used for severe cases, but they are associated with significant side effects. $^{2}$ KPPC should not be confused with keratosis punctata palmoplantaris (KPPP), which features multiple $1-2 \mathrm{~mm}$ pits over the soles of the hands and feet. Unlike KPPC, KPPP is highly associated with colorectal malignancies, atopy and longitudinal nail dystrophy. ${ }^{3}$

Contributors AKB was involved in care of the patient and authorship of manuscript. WW was involved in preparation and editing of the manuscript.
Competing interests None declared.

\section{Patient consent Obtained.}

Provenance and peer review Not commissioned; externally peer reviewed.

\section{REFERENCES}

1 Fox GN. Puzzling palmar papules and pits. J Fam Pract 2005;54:227-30.

2 Just M, Ribera M, Bielsa I, et al. Keratotsis punctata of the palmar creases: report of two cases associated with ichthyosis vulgaris. Br J Dermatol 1999;141:551-3.

3 Kong MS, Harford R, O'Neill JT. Keratosis punctate palmoplantaris controlled with topical retinoids: a case report and review of the literature. Cutis 2004;74:173-9.

Copyright 2016 BMJ Publishing Group. All rights reserved. For permission to reuse any of this content visit http://group.bmj.com/group/rights-licensing/permissions.

BMJ Case Report Fellows may re-use this article for personal use and teaching without any further permission.

Become a Fellow of BMJ Case Reports today and you can:

- Submit as many cases as you like

- Enjoy fast sympathetic peer review and rapid publication of accepted articles

- Access all the published articles

- Re-use any of the published material for personal use and teaching without further permission

For information on Institutional Fellowships contact consortiasales@bmjgroup.com

Visit casereports.bmj.com for more articles like this and to become a Fellow 